\title{
Analysis on the Internationalization Policy of Yunnan Higher Education and Its Development Strategy
}

\author{
Zhu Wen \\ School of Public Finance and Management, Yunnan University of Finance and Economics,Kunming, China \\ zzhuu8952@163.com
}

Abstract-The globalization and integration of the knowledge economy has promoted the in-depth development of China's higher education internationalization capacity building.In the process of internationalization of higher education, the power at the national level is very strong. The central government has adopted national policies and regulations to deploy and guide the development direction of the internationalization of higher education in the country. However, macroeconomic policies have not fully considered the location characteristics and exerted geographical advantages.The differences in economic and cultural development caused by different geographical regions have directly led to different priorities and development directions for the internationalization of higher education in the eastern and western regions of China.Therefore, how to promote the better and faster development of higher education internationalization in Yunnan Province must be based on the guidance of the state's macro-policy, adapt to local conditions, based on the actual situation in the region, fully consider regional characteristics, adopt localized thinking and actions.

Keywords-internationalization policy; policy analysis; education development; localization strategy

\section{THE ISSUES RAISED}

The formulation and evolution of the internationalization policy of higher education directly determines the level of internationalization and its development direction. The question of what kind of policies, policies, and functions can be played in the internationalization of higher education has always been an important part of studying the internationalization of higher education. Therefore, the issue of the promulgation and implementation of the internationalization policy of higher education has not only received extensive attention from the academic community, but in the international exploration and practice, China has also gradually developed an international education model suitable for China.

The internationalization of China's higher education can be traced back to the mid-to-late 1970s. At present, relevant policies have gradually improved. Among them, the development of policy formulation and reform involves four aspects: studying abroad, studying in China, and Chinese and foreign studies. Cooperation in running schools and foreign exchanges and cooperation.With the development of China's higher education internationalization theory, it has accumulated rich practical experience. The promulgation and implementation of policies have become the "lighthouse" for future development. Supporting the internationalization of China's higher education is in line with the national conditions of the country, making the status and role of the policy increasingly prominent. come out.

The internationalization of higher education in Yunnan Province and its related policies are influenced by the entire domestic policy framework. With the inherent autonomy of the policy, the need for international quality education resources is increasing day by day, and it is also beginning to explore the 
internationalization of higher education. Development model.During this period, the internationalization of higher education in Yunnan Province experienced the development trend of implementing the relevant national policies and the same steps of the country, and gradually developed a policy based on its own development level, presenting a new policy picture and the connotation of internationalization. With the introduction of "going out and going out", through the induction and organization, the main content and evolution process of Yunnan' $s$ higher education internationalization policy can be summarized as follows, continuing the international education through public or self-funded study abroad. Talents, based on Yunnan's location advantage, attract Southeast Asian students, but also achieve policy innovation and practical exploration through localization. So how are these stages of development divided? What role does the policy at each stage play? The gains and losses, achievements and shortcomings, innovations and limitations of Yunnan's higher education internationalization policy? These issues are worthy of academic attention and research.

\section{ANALYSIS ON THE INTERNATIONALIZATION OF HIGHER} EDUCATION IN YunNan PROVInCE AND ITS POLICY SuPPORT

Generally speaking, "the relationship between education and the economy is a dialectical mutual causal relationship. They are mutually reinforcing and mutually restrictive relations" (Lu Chengxiao, 2007).Yunnan Province is based on the frontier, backed by the motherland, and rooted in the southwest. Its special geographical location and the limitations of economic development mode determine that its economic and social development level is far below the national average. The backward economic factors in Yunnan directly affect its internationalization. The process, therefore, the academic community proposed that Yunnan relies on the regional advantages of ASEAN to carry out internationalization strategies (Yi Jidong, Cheng Bin, Feng Yongjun, 2007), through the recruitment of students mainly from Southeast Asia and South Asian countries, through innovative training models, Students have the international vision of China-ASEAN.

The process of internationalization of higher education in Yunnan benefits from both national policies and its own factors, making it different in different stages of the development process. From the perspective of the policy changes, the internationalization process can be summarized into three stages, namely, the natural development stage, the slow development stage, and the rapid development stage.

\section{A. Natural development stage: policy vacuum period (before} 1986)

Since 1978, China's higher education internationalization policy formulation and evolution process has experienced intermittent to balanced changes. The policy at the national level was in the exploration period before 1986, and the policy system structure was gradually constructed, but some policies still appear to be inconsistent.

Before 1985, Yunnan Province mainly implemented the national policy of going abroad and studying in China. The local government did not formulate corresponding policies and regulations. At this time, the policy is still in a "vacuum period" , and the internationalization of higher education is at the stage of natural development.

Summarizing Yunnan's experience and gains and losses in implementing national policies can be seen: Since the Chinese government implemented the "self-funded study abroad qualification review" regulations before 1985, the study abroad was mainly based on public affairs.During this special development period, the Yunnan provincial government and the education department have placed more emphasis on how to complete the government's target tasks according to regulations and requirements. This also requires all universities and relevant education management departments to set up international exchange departments or Some departments undertake the functions of international education cooperation. There is a lack of overall planning and development goals for the internationalization of higher education. The selection and acceptance of international students can only be carried out through government, universities, research institutes and other educational institutions. The policies that can be implemented are also national-level, and the localization of local higher education is reflected. Development is difficult to achieve, but through the implementation of national-level policies, Yunnan Province has accumulated practical experience in the internationalization of higher education. 


\section{B. Slow development stage: policy window period}

(1986-2006)

With the acceleration of China's internationalization process and the improvement of the policy environment, the policies at the national level have greatly promoted the development of Yunnan's policies and created a good historical opportunity, which enabled Yunnan Province to open a policy window and benefit from the policy support of Yunnan Province. Higher education has begun to make great strides towards internationalization.In 2000, the Yunnan Provincial People's Government issued a notice on the "Opinions on the Implementation of the Action Plan for Education Revitalization in the 21st Century in Yunnan Province" , and also proposed that "education should be modern, world-oriented, and future-oriented", with the aim of determining the development of higher education. The guiding ideology of education internationalization, but there is still a lack of policies that can be implemented concretely. The period of internationalization of higher education is in a period of slow development.

1) "Going out" and "bringing in" strategies

In 2002, the Ministry of Education specially set up a special project for talent cultivation in the western region in line with the national strategy for the development of the western region. Yunnan Province has formulated a series of international education policies based on central support and adopted various channels to expand the scale of study abroad. Going out of the strategy, the public and private students studying abroad are getting bigger and bigger. At the same time, Yunnan universities and universities have adopted a variety of policies to attract foreign students from ASEAN to study in China, that is, the "introduction" strategy. The introduction of these policies has greatly improved the internationalization level of higher education in Yunnan Province.

2) Exploration of international cooperation and exchanges

Under the premise of following the national macro-policy internationalization policy, Yunnan Province began to explore the internationalization policy of higher education in line with Yunnan's own regional characteristics and economic and social development.A number of universities, such as Yunnan University and Yunnan University of Finance and Economics, have successively conducted research on Sino-foreign cooperation in running schools and exchanges and cooperation.However, due to differences in national policies and local implementation, some of the universities that first cooperated in running schools were terminated due to the approval of Chinese-foreign cooperative education projects, while the Yunnan University of Finance and Economics and the universities in Australia, the United States, and the United States have obtained bachelor degree programs. Approved by the State Council's degree office, and gradually became the benchmark for Yunnan-China cooperation in running schools (Lu Hao, 2015).During this period, colleges and universities have made active exploration and innovation in the international exchange and cooperation of higher education, laying a solid foundation for the internationalization of Yunnan higher education.

Communicate and cooperate with neighboring countries in the field of education. First, actively cultivate small talents and establish an international talent training base. Second, we must strengthen the construction of international courses, actively introduce and use English textbooks and teach in English, and run Sino-foreign cooperation schools. Teacher-student exchanges will lay the foundation and expand the field of foreign cooperation.

3) Achievements and shortcomings in the policy window

The policy has gradually opened up the situation of international exchanges and cooperation in education, and the development of regional higher education integration has achieved outstanding results. While the construction of the "China-ASEAN Free Trade Area" is developing in depth, the economic cooperation in the Minjiang-Mekong sub-region is also heating up.Under this macro background, Yunnan Province, located in the southwestern border of China, has also ushered in a rare development opportunity and a good policy environment.However, in the process of policy construction, the driving force of external change and the internal dynamic mechanism are insufficient, resulting in the lag of policy.That is to say, the education internationalization policy of Yunnan Province in the province is based on the national policy system, combined with the actual situation of the province to carry out policy use and innovation needs, the internal development momentum is greater than the support given by the national 
policy, but the national level policy is difficult to " "Going to the ground", the policy formulated by the local government, its policy attribute is "nesting" of policies at the national level, does not form an overall policy framework and effectively supports the development of higher education institutions towards better and higher levels.

\section{Rapid development stage: policy innovation and}

\section{fragmentation (2006-present)}

The support system for internationalization of higher education has gradually improved. On the one hand, the policy of Yunnan Province has the characteristics of "localization". On the other hand, it continues to use the framework structure of the original national level and presents the characteristics of "fragmentation". The characteristics of these two aspects show that the central policy of the policy change process is easily hindered and involved by the original policy, and the policy operability and flexibility are insufficient, which leads to the policy stakeholders' " realization" in the implementation process due to the actual consideration of all parties. Avoiding harm, and the lack of motivation mechanisms for innovation policies.

\section{1) Establishment of the "bridgehead" strategy}

From 2008 to 2011, the Yunnan Provincial Government issued the "Bridgehead" strategic series of policy measures, grasping the construction of China-ASEAN Free Trade Area and the historical opportunity period of cooperation and exchange between China and Southeast Asia and South Asia, and proposed to accelerate Yunnan education. The main tasks of the internationalization process and safeguard measures will improve the level of opening up in Yunnan Province. With the support of this policy, the number of students from Southeast Asia, South Asia and other countries has increased rapidly, from more than 4,000 in 2006 to more than 10,000 in 2012.

\section{2) "Localization" thinking and action}

In 2010, the Provincial Party Committee Work Committee and the Provincial Department of Education proposed the idea of building an international education home, education foundation, exchange and cooperation, and personnel training platform to accelerate the province's internationalization. Through its own actions and efforts, we will strive to achieve international development and promote internal policies. Implemented on the ground.To this end, the education department of Yunnan Province has introduced relevant measures to strengthen the construction of the teaching staff, enhance the international teaching ability and level of teachers, and actively introduce foreign intelligence to give full play to the role of foreign teachers. At the same time, decentralize the authority of relevant departments of the provincial government and provide financial and project support. The universities in Yunnan Province have gained more autonomy. They have issued regulations on the management of foreign students and talent training programs, and strengthened the study of foreign advanced education concepts, models and systems, and combined them with the educational practice of the region to launch high-level Education internationalization "localization" action.At the same time, it will establish a joint training base with South Asian countries in Southeast Asia to promote international Chinese and cultivate small language talents, and realize the "going out" strategy to make up for the shortcomings of not cooperating with schools in Southeast Asian countries.

\section{3) Policy innovation transformation and limitations}

The internationalization development and policy system of higher education in Yunnan Province is increasingly compatible, and its actual situation has become the driving mechanism for policy innovation.Yunnan has both dual characteristics of underdeveloped areas and border ethnic minority areas. When promoting the internationalization of higher education, Yunnan Province is affected by strategies such as "Western Development", "Bridgehead" and "One Road and One Belt" . The roads of developed provinces and cities, at the same time, accept the international development plan of higher education at the national level, and draw on the useful experience of higher education internationalization in developed countries to form a higher education international with Chinese characteristics, which is in line with the geographical advantages of Yunnan Province and can be in line with international standards. The policy support system, this key factor together has become the driving force behind policy innovation and model transformation.

But it is also necessary to see that the internationalization of higher education in Yunnan Province still needs many conditions. The internationalization of higher education is not only limited to studying abroad and studying in China, but also 
pays more attention to the cooperation of colleges and universities, and is committed to improving the level of education management and building an internationalized talent training system. The China-ASEAN framework has become the key research object of the province's internationalization. Therefore, based on the strategy of "bridgehead" and "one road along the way" , the internationalization of higher education in Yunnan must be integrated with the "characteristics" of Southeast Asia to cultivate talents in Southeast Asia's international vision.

\section{THE OPTIMIZATION STRATEGY OF YUNNAN'S HIGHER} EDUCATION INTERNATIONALIZATION POLICY SYSTEM

On the basis of drawing on and learning from the useful experience of internationalization policies for higher education at home and abroad, Yunnan Province needs to fully consider its own actual situation. From the three main aspects of "going out", "bringing in" and "Chinese-foreign cooperation in running schools", how to improve and optimize the system of pointing out higher education internationalization policies in Yunnan Province.

\section{A. "Going out" is in line with internationalization}

Fully grasp the construction of the "China-ASEAN Free Trade Area" and the historical opportunity period of comprehensive cooperation between China and Southeast Asia and South Asian countries. Yunnan higher education should further study foreign education concepts, international courses, and employ foreign teachers to introduce teaching methods and training models. Consider the characteristics of development stage, geographical factors and economic and social situation, and improve the "going out" policy recommendations from both students and teaching resources.

1) Due to the realistic limitations of its location in the frontier and relatively backward economic development, Yunnan Province should increase the intensity of sending out local students in the process of implementing the "going out" strategy, encouraging and supporting local outstanding scholars to developed countries. Studying abroad, studying the advanced experience of running a school and teaching methods, and laying the foundation for further promoting the internationalization of higher education in Yunnan Province.
2) Yunnan Province is adjacent to Southeast Asia and South Asian countries, and its economic and cultural development level is slightly higher than that of ASEAN countries. Therefore, in the process of implementing the "going out" strategy, Yunnan Province should make full use of relatively excellent educational resources to help and optimize the quality of higher education in Southeast Asia, South Asia and other countries, and further increase cooperation in running schools.

\section{B. "Introduction" integrated education system}

Yunnan Province is rooted in the southwest and adjacent to Southeast Asia. It is an important hub for China's contacts and exchanges with Southeast Asia and South Asia, and it has its unique geographical advantages. While implementing the "going out" strategy, through the "introduction" strategy, we will share educational resources and maximize the complementary advantages. In the process of implementing the "bringing in" strategy, it is also necessary to consider both students and teaching resources.

1) In the development of the "introduction" strategy, it is necessary to adapt to local conditions, identify targets, increase the intensity of propaganda of universities in Yunnan Province to ASEAN and Southeast Asian countries, and draw on the beneficial experience of Guangdong and other provinces to send universities to Southeast Asia and South Asia. The state introduces the basic conditions of its universities and the preferential policies for international students, and adopts various measures to attract students from ASEAN and Southeast Asia to study and improve the education system through teaching practice.

2) In the development of the "introduction" strategy, we must be good at learning, fully introduce the high-quality teaching resources of western developed countries, combine existing educational resources and concepts, and reshape the entire education system with practical experience. In order to promote the reform of higher education in Yunnan Province, improve the quality of higher education in Yunnan Province, optimize and innovate the model of higher education in Yunnan Province.

\section{Explore a good Sino-foreign cooperation model}

Sino-foreign cooperative education is one of the 
important ways to internationalize education. It is necessary to encourage universities in Yunnan Province to actively explore various modes of cooperation with other universities in other countries to develop various forms of learning exchange programs. At the same time, focusing on the development of internationalization of higher education in Southeast Asia and South Asian countries is in line with the current practice of higher education in Yunnan Province and has important practical significance. We will vigorously support and develop cooperation with developed countries to run schools. Through the Sino-foreign cooperation model, we will promote the implementation of the "Going Global, Introducing" strategic objectives, better adapt to the development needs of higher education internationalization, and be in line with the world.

1) In the process of promoting the internationalization of higher education, Yunnan Province should give full play to its unique advantages, focus on broadening the cooperation and exchanges with higher education institutions in Southeast Asia and South Asia, and actively introduce quality education resources, with planned and step-by-step We will carefully select the objects to establish an international cooperation and cooperation relationship in higher education. At the same time, we will support and encourage higher education institutions in the province to establish exchanges and cooperation with other Western countries in terms of cooperation in running schools, teacher exchanges, language education, and summer camps.

2) Establish cooperation and exchange institutions and platforms, and pay special attention to special fund support. Establishing international cooperation and exchange institutions and platforms for higher education and carrying out multi-channel and in-depth cooperation is an important measure to enhance the internationalization of higher education in Yunnan Province. Through the establishment of foreign language tutoring classes for international students, international research centers and teacher international training centers, it can lay the foundation for the internationalization of higher education in Yunnan Province. At the same time, we must pay attention to the support of special funds, such as the establishment of special funds for international exchanges at the provincial, municipal, and school levels to support international exchanges and cooperation at all levels.

\section{REFERENCES :}

[1] Cheng Wenzhang, Tang Ying, Tian Jing. Research on the Internationalization Strategy of Higher Education in Yunnan Province [M]. Beijing: Science Press, 2008: 33-57.

[2] Anonymous. The Evolution and Development of the Study Abroad Policy in New China [N]. China Youth Daily, 2011-01-04.

[3] Ministry of Education of the People's Republic of China. China Education Statistics Network [EB/OL].http://www.stats.edu.cn/sjcx.aspx.

[4] State Council of the People's Republic of China. National Medium- and Long-Term Education Reform and Development Plan (2010-2020) [Z].2010-07-29.

[5] Education Committee of the People's Republic of China. Interim Provisions on Sino-foreign Cooperation in Running Schools [Z].1995-01-26.

[6] Notice of the State Council of the State Council of the People's Republic of China on Strengthening the Management of Degrees in Sino-foreign Cooperation in Running Schools[Z].1996-01-22.

[7] Ministry of Education of the People's Republic of China. Implementation Measures for the Regulations of the People's Republic of China on Chinese-Foreign Cooperation in Running Schools [Z].2004-03-01.

[8] Ministry of Education of the People's Republic of China. Thoughts and Measures for China's Education Reform and Development in 2005 [Z].2005-01-27.

[9] Li Zhenquan, Chen Xia. A Comparative Study of the Internationalization Policies of Higher Education in Britain, Germany and France[J].Science and Technology Progress and Policy,2004,11.

[10] Wang Xia, Qian Xiaolong. The Status Quo and Experience of American Higher Education Internationalization and China's Countermeasures[J].Global Education Outlook,2010,11(39).

[11] Education Secretary to Host International Education Summit [EB/OL].http://www.america. Gov/st/washfile-english/2005/December/ 20051228175350aawajuk().1687586.html, 2010-08-19.

[12] National Security Language Initiative for Youth (NSLI-Y) [EB/OL].http://exchanges.state.gov/Youth/programs/ nsli.html.2010-08-19.

[13] Senator Paul Simon Study Abroad Foundation Act [EB/OL].http://paulsimoninstitute.org/Index.php?option=com_content\& view $=$ cate gory \&layout $=$ blog $\& \mathrm{id}=88 \&$ Itemid $=264,2010-08-19$.

[14] General Office of the Ministry of Education of the People's Republic of China. China Education Yearbook (2002-2011) [M]. Beijing: People's Education Press.

[15] Yang Yunhui. Yunnan cooperates with neighboring countries to implement the "going out" strategy of colleges and universities [N]. China Education News, 2007-2-3(1).

[16] Yi Jidong, Zhao Wenhua, Luo Mingdong. Research on Some Major Issues in Yunnan Higher Education Reform and Development [M]. Beijing: Science Press, 2004.

[17] Lu Chengxiao. Non-equilibrium analysis of regional higher education and economic development in China [D]. Fujian: Xiamen, 2007.

[18] Yi Jidong, Cheng Bin, Feng Yongjun. Research on the Development Path of Yunnan-ASEAN Higher Education Internationalization[J]. Higher Education Research, 2007, (3): 52-56.

[19] Lu Xuan. Research on Sino-foreign Cooperation in Running Schools in Yunnan Universities [D]. Yunnan Normal University, 2015. 